Article

\title{
Assessment of the Anxiety Level of Andalusian Podiatrists during the COVID-19 Pandemic: The Increase Phase
}

\author{
Samuel Vilar-Palomo ${ }^{1} \oplus$, Manuel Pabón-Carrasco ${ }^{2, *}{ }^{\circledR}$, María Luisa Gonzalez-Elena ${ }^{2}$, \\ Lucia Ramírez-Baena $^{3}{ }^{\circledR 0}$, Isabel Rodríguez-Gallego ${ }^{3}$ and Aurora Castro-Méndez ${ }^{2}{ }^{\circledR}$ \\ 1 Hospital Virgen del Rocío, Unidad de Anestesiología y Reanimación, Servicio Andaluz de Salud, Av. Manuel \\ Siurot, SN., 41013 Seville, Spain; samuelvilarpalomo@hotmail.com \\ 2 Faculty of Nursing, Physiotherapy and Podology, Universidad de Sevilla, C/Avenzoar 6, 41009 Seville, Spain; \\ maruchi1@us.es (M.L.G.-E.); auroracastro@us.es (A.C.-M.) \\ 3 Spanish Red Cross Nursing School, Universidad de Sevilla, Sevilla, Spain, Avda de la Cruz Roja, $\mathrm{n}^{\circ} 1$ Dpdo, \\ 41009 Sevilla, Spain; luciarb@correo.ugr.es (L.R.-B.); isroga@cruzroja.es (I.R.-G.) \\ * Correspondence: mpabon2@us.es; Tel.: +34-954-35-09-97; Fax: +34-954-35-09-97
}

Received: 21 September 2020; Accepted: 23 October 2020; Published: 26 October 2020

\begin{abstract}
Coronavirus disease (COVID-19) is caused by SARS-CoV-2 and represents the causative agent of a potentially fatal disease that is of great global public health concern. COVID-19 is a respiratory disease produced by the coronavirus family. The World Health Organization declared the disease a pandemic on 11 March 2020. Podiatrists are in a peculiar situation regarding the COVID-19 pandemic: that of a health professional aspect and the singularity that most of them practise as self-employed workers. The aim of the study is to evaluate in a group of podiatrists, working at a national level, their knowledge, perception and degree of anxiety related to the COVID-19 pandemic via the use of a questionnaire specifically developed to this end in the initial phase of the pandemic. We employed a transversal descriptive study with 302 participants, with a purposive sampling technique. The degree of perception and knowledge of the podiatrists about COVID-19 was analysed as well as the cognitive impact of the situation of confinement. The results showed that the podiatrists perceive this situation as serious at the economic and health level, that they have a thorough knowledge of the disease and that they are in a moderate to severe percentile of anxiety. Additionally, $76.2 \%$ cancelled their usual work. The COVID-19 pandemic is negatively perceived by this group of podiatrists at the personal, professional, health and economic level, with even a state of anxiety being produced.
\end{abstract}

Keywords: COVID-19; SARS virus; pandemic; anxiety; psychological

\section{Introduction}

On 11 March 2020, the World Health Organization (WHO) declared as a pandemic a respiratory disease due to coronavirus, called COVID-19 [1]. The first cases of the disease were reported on December 2019 in Wuhan (China) and patients were affected by a pneumonia of unknown origin. It was established later that it was an infection caused by a type of virus belonging to the coronavirus family [2]. SARS-CoV-2 is an RNA virus, with a typical crown-like appearance under an electron microscope due to the presence of glycoprotein spikes on its envelope [3]. It is known that are four genera of coronaviruses (CoVs): (I) $\alpha$-coronavirus (alphaCoV), (II) $\beta$-coronavirus (betaCoV), (III) $\delta$-coronavirus (deltaCoV) and (IV) $\gamma$-coronavirus (gammaCoV). Previous outbreaks of $\mathrm{CoVs}$ include the severe acute respiratory syndrome (SARS) CoV and the Middle East respiratory syndrome (MERS) CoV [3-5]. The coronavirus has a zoonotic origin, and diverse studies indicate bats as the main transmitter of the virus to 
humans [6,7]. However, transmission among humans takes place through contact with people who are carriers of the virus, who act as spreading vectors of it to healthy people [8]. The spread among humans seems to be done through direct contact via respiratory secretions in the form of droplets when coughing, sneezing or speaking, or through contact with these secretions deposited on surfaces and the virus is fundamentally introduced into the organism through the mouth, nose or eyes [9-11].

The symptoms of COVID-19 infection appear after an incubation period of approximately 5.2 days [9]. The period from the onset of COVID-19 symptoms to death have ranged from 6 to 41 days, with a median of 14 days [12]. The symptoms shown due to the infection by COVID-19 are varied, from asymptomatic patients who are detected as positive via carrying out a test, to patients who experience a process of bilateral pneumonia which can even jeopardise their vital state, or more common symptoms such as cough, fever and dyspnea [9,13-16]. In spite of the pathological mechanisms of the disease still being completely unknown, other symptoms which have been revealed are headaches, throat pains, gastrointestinal disorders and vomiting, among others $[2,13,15,17]$. As to the distribution of the disease according to age and sex, it is estimated that most of the cases (approximately $80 \%$ ) are in the range of 30 to 69 years of age, the average age being around 58 years old, and $51 \%$ of those affected are men $[2,9,15,16,18]$.

The COVID-19 disease can affect certain at-risk groups, such as people over 65 years old with chronic respiratory illnesses, diabetes, heart disease, cancer, and severe obesity or who are immunosuppressed, among others $[19,20]$. At present, there are no specific antiviral drugs or a vaccine against COVID-19 infection for the potential therapy of humans. The only option available is using broad-spectrum antiviral drugs, such as nucleoside analogues and also HIV protease inhibitors. [21]. Another report showed that the broad-spectrum antiviral remdesivir and chloroquine are highly effective in the control of COVID-19 infection in vitro [22].

In epidemiological terms, according to the WHO, on 7 October, there were 37,594,218 cases confirmed worldwide, distributed over 213 countries, having caused 1,077,326 deaths [23]. In Spain, according to the data of the Ministry of Health, on 7 October 2020, there were 888,968 confirmed cases of COVID-19, of whom 32,929 died [24].

At the national level, since the Spanish government decreed the state of alarm on 14 March 2020 [25], work activity gradually decreased to the point of only allowing that of firms which the government considered essential to maintain basic services during the health crisis. This was regulated through the Royal Decree-Law 10/2020 of 29 March [26].

COVID-19 has had a great impact on the mental health of healthcare professionals. A systematic review published in July 2020, which includes 13 articles analysing the impact of the pandemic on the mental health of nurses, doctors and other health professionals, shows a medium-high level of anxiety in said professionals, in addition to other pathologies such as depression, nervousness and insomnia [27].

In the area of health professions which practise their professional activity privately, this decree-law has had a very significant impact on podiatrists.

Professional podiatrists have peculiar characteristics with respect to other health professions. Firstly, their main aim is to carry out activities related to the prevention and treatment of foot problems, improving people's health. Professionals podiatrists are fundamentally self-employed, not generally being included in the public health system, so the current situation has a negative personal and economic impact on them.

The non-explicit closure of health establishments, as well as the few patients who attended consultations due to the obligatory confinement, has had a negative impact on their incomes. There is also the current obligation to continue with the expenses of maintaining private consultancies (rent, supplies, social security quota, etc.). At the same time, there is the emotional impact of the global pandemic itself. Furthermore, podiatrists do not have the preventative means that health professions at a hospital level have.

Due to the situation of professional podiatrists mentioned above, and in view of the current health crisis because of the COVID-19 pandemic, it is necessary to carry out this study to assess the effects 
of this situation on the personal and economic level of this group. Based on the results obtained, activities can be carried out to improve the degree of knowledge and decrease anxiety concerning COVID-19 in this health group.

The aim of the study is to evaluate in a group of podiatrists, working in Spain at an autonomic level, the level of anxiety and the relationship that this has with the measures implemented, their work situation and their perception of the pandemic.

The second objective of the study is to know the degree of knowledge about COVID-19 of this group.

This is done via the use of a questionnaire specifically developed for this purpose in the initial phase of this pandemic.

$\mathrm{H}_{\mathrm{o}}$ : the anxiety suffered by podiatrists is not related to their perception of their work or personal situation.

\section{Materials and Method}

\subsection{Research Design}

An observational, transversal study with a purposive sampling technique was carried out. The initial chronological phase was from 11 March to 28 March 2020. This was set up with the indications proposed by Strengthening the Reporting of Observational Studies in Epidemiology (STROBE).

\subsection{Sample}

The study population $(n=302)$ was made up of working podiatrists who, after being informed of the nature of the research, voluntarily chose to be part of it. A greater female participation $(66.6 \%)$ and those licenced in podiatry $(65.6 \%)$ predominated. The average age was 38.02 years (SD 8.5; range 22-63). Ninety-five percent of the podiatrists were self-employed.

In all the cases, the principles established in the Helsinki Declaration and the agreements with these principles were met [28]. The ethical committee of the Official College of Podiatrists of Andalusia (COPOAN) and Hospital Virgen de Valme, Seville (Spain) CEI approved the study. The date of approval was 24th March of 2020 (1114-N-20).

\subsection{Procedure and Sampling Technique}

The study population, working podiatrists $(n=302)$, was recruited via disseminating the questionnaire through telematic platforms and was coordinated through the Professional Organisation of Podiatrists of Andalusia. The inclusion criteria were: graduates in podiatry currently working in Spain with a self-employed professional activity.

The information provided by the questionnaire was dealt with anonymously and confidentially with use limited to attaining the aims of this research project. The questionnaire was administered in relation to the progressive rise in the number of those affected by the COVID-19 pandemic. The chronology chosen to carry out this questionnaire coincided with the data published by the Spanish Ministry of Health, Consumption and Social Welfare, where the period of infection with a rising number of cases was indicated, without the highest peak in infections because of the COVID-19 epidemic being reached during the survey [20].

Chronology of the data collection: from the 11th to the 28th of March 2020. This was an initial period of infection, the maximum number of infections in Spain had not yet been attained.

\subsection{Measures}

The sociodemographic variables were compiled via an ad hoc questionnaire concerning age, sex, marital status, level of studies (licenced, graduate, doctor) and the current employment situation (self-employed or employee). The number of minors in the home was considered. 
A previous questionnaire used to assess the perceived risk, anxiety and behavioural responses of the general public during the first phase of the influenza A (H1N1) pandemic in the Netherlands was adapted [29]. This questionnaire was previously based an online questionnaire that was based on an existing questionnaire used in studies on risk perception and precautionary behaviours of the general public during outbreaks of SARS [30] and avian influenza [31]. The Cronbach's alphas of the constructs ranged from 0.7 to 0.9 .

A re-adaptation to the new agent was performed and the same structure was maintained. On the other hand, new questions related to the idiosyncrasy of the group were implemented.

In addition, the Anxiety Situations and Responses Inventory (ASRI) was used [32]. The ASRI enables evaluating the cognitive responses of anxiety and detects, in the first instance, physiological and motor responses in specific situations. Its Cronbach's alpha coefficient is $\alpha=0.90$ and it has 12 questions which assess the general level of anxiety (a common feature of an anxious personality). It identifies three systems of independent response (what we think, regulated by the cognitive system; what we feel at the physical level, or physiological system; and what we do, or behavioural-motor system). The minimal obtainable score out of the twelve anxiety answers is, by adding up the scores, zero ( 0 by 12 symptoms); the maximum score is 48 ( 4 by 12).

Finally, the questionnaire had the following structure:

1. Sociodemographic variables: age, sex, nationality.

2. Academic education: licenced, graduate or doctor in podiatry.

3. Professional activity social security system: self-employed or employee.

4. Marital status: single, married, divorced, domestic partnership, widow/er.

5. Block corresponding to knowledge of COVID-19.

6. ASRI questionnaire of anxiety about COVID-19 from the Spanish Society for the Evaluation of Anxiety and Stress.

7. Block corresponding to perceived severity of COVID-19.

8. Block corresponding to perceived effectiveness of the measures before the state of alarm.

9. Block corresponding to perceived effectiveness of the measures after the state of alarm.

10. I consider that ...

11. Block corresponding to the information received.

12. Measures taken to avoid infection.

Exploratory analysis of the questionnaire was performed. The Kaiser-Meyer-Olkin (KMO) tes and Bartlett's sphericity test evaluated the applicability of the factor analysis. The statistics show excellent sample adequacy (KMO: 0.905; Bartlett: 1610.29, p: 0.0001), so exploratory factorial analysis of the ASRI questionnaire of anxiety about COVID-19 was carried out. Three components with self-values of more than one were found that explained $67.45 \%$ of the variance. For the rotated factorial matrix, the orthogonal rotation method called varimax with Kaiser normalisation (converged on three itineraries) was used. In sums of rotations of squared loads, factor 1 explained $50.51 \%$ of variance factor $2,9.59 \%$, and factor 3,7.34\%. The Cronbach's alpha coefficient that was obtained was $\alpha=0.85$ after translation and re-adaptation.

\subsection{Statistical Analysis}

The size of the sample was calculated for a power of 0.95 , with an alpha error of 0.05 and a size effect of 0.25 (G* Power 3.1.9.4, Franz Faul, University of Kiel, Kiel, Germany). This calculation produced a necessary sample size of 280 subjects. However, the EPIDAT programme was used (expected ratio of $50 \%$ and precision of 5\%) after finding the number of collegiate podiatrists in 2019 in the community of Andalusia (1500). A sample size of 305 subjects was recommended. Three-hundred and two subjects were finally recruited [33].

Data exploration was done, generating summary statistics for all the cases. This procedure is used to identify atypical or extreme values and characterise differences between groups of cases. Likewise, 
it enables identifying if the statistical techniques considered are appropriate and indicates the need to transform the data or use non-parametric tests. The numerical variables (quantitative) are summarised with means and standard deviations or, in the case of very asymmetric distributions, through medians and percentiles (P25 and P75), and frequencies and percentages are used for the non-numerical variables (qualitative). The data were analysed using SPSS 24.0 computer software (SPSS Science, Chicago, IL, USA). The Kolmogorov-Smirnov test was applied to determine the distribution of the variables.

The Student's t-test was used to verify the score obtained via the ASRI questionnaire and the parameters. On the other hand, the ANOVA test was used when the qualitative variable was polytomous. Non-parametric tests were used in the case of not meeting normality criteria. The magnitude of differences in pairwise comparisons was tested using the standardised effect size of Cohen's $d$ and eta squared $\left(\eta^{2}\right)$. The level of significance adopted for all the statistical analyses was $p<0.05$ [34].

\section{Results}

\subsection{Characteristics of the Study Sample}

A global sample of 302 subjects was used. An analysis of the sociodemographic and general data of the sample is shown in Table 1.

Table 1. Sociodemographic and general data of the sample.

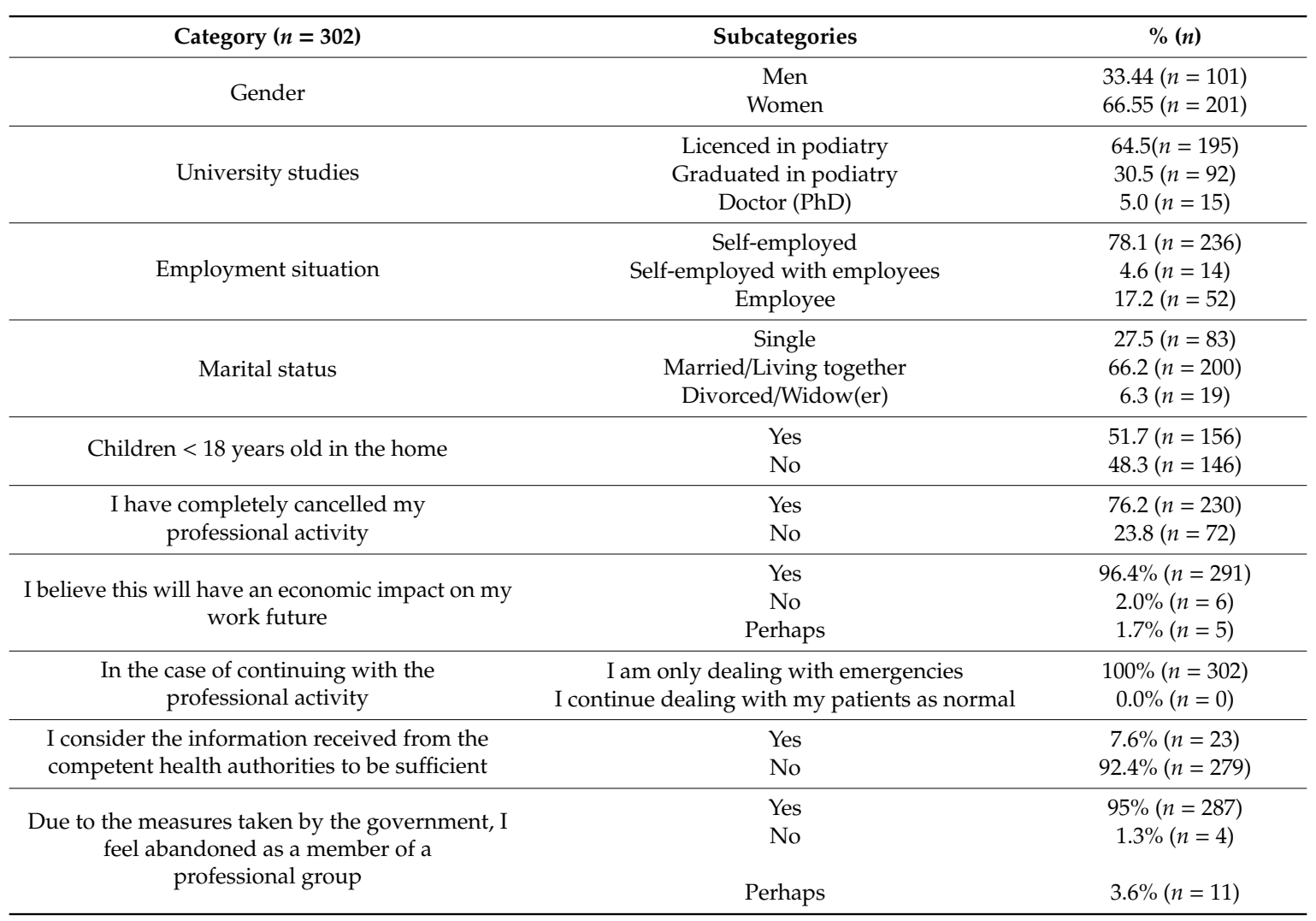

A descriptive analysis of the competences assessed in the questionnaire was done: "knowledge of COVID-19", "perceived severity", "perceived effectiveness of the measures before the state of alarm", "perceived effectiveness of the measures after the state of alarm", "information received from the competent authorities" and "perception of the group" (Table 2).

To end the section of descriptive statistics an analysis of the level of anxiety was carried out (Table 3).

On the other hand, the weighted average of the ASRI questionnaire is 17.66 (SD 10.12, CI 95\%, range 16.51-18.80), this indicates that the group has an anxiety level that is between moderate and 
severe. This is disaggregated into three dimensions, with a weighted average of $8.7 \pm 3.5$ in the cognitive area, $4.45 \pm 4.62$ in the physiological area and $4.49 \pm 3.09$ in the motor dimension.

\subsection{Inferential Analysis}

An analysis of the level of anxiety and its dimensions with the rest of the parameters studied was done (Table 4). Those variables which have a direct relation with anxiety are related. These were selected in accordance with the descriptive statistics or those sociodemographic variables which could outline the profile of the group.

The data are statistically significant for the area of work, perception, susceptibility, gender, marital status, treatment received and information given by the government.

Table 2. Descriptive analysis of the dimensions evaluated.

\begin{tabular}{|c|c|c|c|c|c|}
\hline Knowledge & YES & NO & DK/DA & & \\
\hline 1. COVID-19 is caused by a new virus & $81.1 \%$ & $16.6 \%$ & $2.3 \%$ & & \\
\hline 2. A vaccine against COVID-19 is available & $1.0 \%$ & $99.0 \%$ & $0.0 \%$ & & \\
\hline $\begin{array}{l}\text { 3. COVID-19 can be transmitted by human to } \\
\text { human contact }\end{array}$ & $96.0 \%$ & $3.6 \%$ & $0.3 \%$ & & \\
\hline $\begin{array}{l}\text { 4. The symptoms of COVID-19 are visible in all } \\
\text { the cases }\end{array}$ & $2.0 \%$ & $98.0 \%$ & $0.0 \%$ & & \\
\hline 5. Pets transmit COVID-19 & $1.0 \%$ & $91.4 \%$ & $7.6 \%$ & & \\
\hline 6. COVID-19 is transmitted by wild animals & $41.7 \%$ & $35.8 \%$ & $22.2 \%$ & & \\
\hline 7. It has a virulence similar to conventional influenza & $47.4 \%$ & $49.7 \%$ & $3.0 \%$ & & \\
\hline Perceived severity & Very high & High & Medium & Low & Very low \\
\hline 8. Severity of COVID-19 & $22.8 \%$ & $44.4 \%$ & $28.8 \%$ & $1.7 \%$ & $2.3 \%$ \\
\hline $\begin{array}{l}\text { 9. Risk of contracting the disease because of my age } \\
\text { or presence of previous pathologies }\end{array}$ & $6.0 \%$ & $18.2 \%$ & $21.2 \%$ & $18.9 \%$ & $35.8 \%$ \\
\hline 10. COVID-19 is harmful for my health & $37.1 \%$ & $22.2 \%$ & $27.2 \%$ & $9.3 \%$ & $4.3 \%$ \\
\hline 11. Perceived susceptibility & $11.6 \%$ & $24.2 \%$ & $39.7 \%$ & $14.9 \%$ & $9.6 \%$ \\
\hline 12. Perceived possibility of getting infected & $22.8 \%$ & $28.1 \%$ & $27.5 \%$ & $17,2 \%$ & $4.3 \%$ \\
\hline $\begin{array}{l}\text { 13. Perceived possibility of getting infected in } \\
\text { comparison with others }\end{array}$ & $19.5 \%$ & $27.8 \%$ & $26.5 \%$ & $12.9 \%$ & $13.2 \%$ \\
\hline $\begin{array}{l}\text { Perceived effectiveness of the measures before the } \\
\text { state of alarm }\end{array}$ & Very high & High & Medium & Low & Very low \\
\hline 14. Avoid crowded places & $67.5 \%$ & $5.0 \%$ & $13.9 \%$ & $8.6 \%$ & $5.0 \%$ \\
\hline 15. Carry out better hygiene & $78.8 \%$ & $11.3 \%$ & $7.0 \%$ & $2.3 \%$ & $0.7 \%$ \\
\hline 16. Use of mask & $51.0 \%$ & $14.9 \%$ & $18.9 \%$ & $8.9 \%$ & $6.3 \%$ \\
\hline 17. Seek medical attention if flu symptoms appear & $37.7 \%$ & $15.2 \%$ & $27.2 \%$ & $9.9 \%$ & $9.9 \%$ \\
\hline 18. Stay at home & $74.8 \%$ & $9.6 \%$ & $9.6 \%$ & $2.6 \%$ & $3.3 \%$ \\
\hline $\begin{array}{l}\text { 19. Continue with my work activity, increasing the } \\
\text { prevention measures }\end{array}$ & $15.6 \%$ & $9.6 \%$ & $18.2 \%$ & $15.9 \%$ & $40.7 \%$ \\
\hline $\begin{array}{l}\text { Perceived effectiveness of the measures after the } \\
\text { state of alarm }\end{array}$ & Very high & High & Medium & Low & Very low \\
\hline 20. Avoid crowded places & $89.7 \%$ & $5.0 \%$ & $4.0 \%$ & $1.0 \%$ & $0.3 \%$ \\
\hline 21. Carry out better hygiene & $93.7 \%$ & $5.0 \%$ & $1.3 \%$ & $0.0 \%$ & $0.0 \%$ \\
\hline 22. Use of mask & $60.9 \%$ & $17.2 \%$ & $13.2 \%$ & $4.6 \%$ & $3.3 \%$ \\
\hline 23. Seek medical attention if flu symptoms appear & $48.3 \%$ & $17.5 \%$ & $22.5 \%$ & $6.6 \%$ & $5.0 \%$ \\
\hline 24. Stay at home & $80.5 \%$ & $8.9 \%$ & $7.9 \%$ & $1.0 \%$ & $1.7 \%$ \\
\hline $\begin{array}{l}\text { 25. Continue with my work activity, increasing the } \\
\text { prevention measures }\end{array}$ & $25.2 \%$ & $7.3 \%$ & $12.3 \%$ & $11.6 \%$ & $43.7 \%$ \\
\hline Perception & Totally agree & Agree & $\begin{array}{l}\text { Neither agree } \\
\text { nor disagree }\end{array}$ & Disagree & Totally disagree \\
\hline $\begin{array}{l}\text { 26. The threat is exaggerated by the media and } \\
\text { the government }\end{array}$ & $8.6 \%$ & $7.9 \%$ & $10.6 \%$ & $12.9 \%$ & $59.9 \%$ \\
\hline 27. The situation is worse than what was predicted & $86.1 \%$ & $8.3 \%$ & $2.6 \%$ & $1.0 \%$ & $2.0 \%$ \\
\hline 28. There is nothing we can do about it & $10.3 \%$ & $10.6 \%$ & $19.5 \%$ & $14.6 \%$ & $45.0 \%$ \\
\hline 29. The situation breeds a sense of powerlessness & $76.5 \%$ & $10.3 \%$ & $7.0 \%$ & $3.6 \%$ & $2.6 \%$ \\
\hline 30. Confinement is the only option & $58.3 \%$ & $22.2 \%$ & $10.9 \%$ & $4,6 \%$ & $4.0 \%$ \\
\hline $\begin{array}{l}\text { 31. As a health professional I consider the } \\
\text { information received by the government to } \\
\text { be reliable }\end{array}$ & $0.7 \%$ & $6.6 \%$ & $17.5 \%$ & $27.5 \%$ & $47.7 \%$ \\
\hline
\end{tabular}

Note: DK/DA: do not know/did not answer. 
Table 3. Valuation of the level of anxiety.

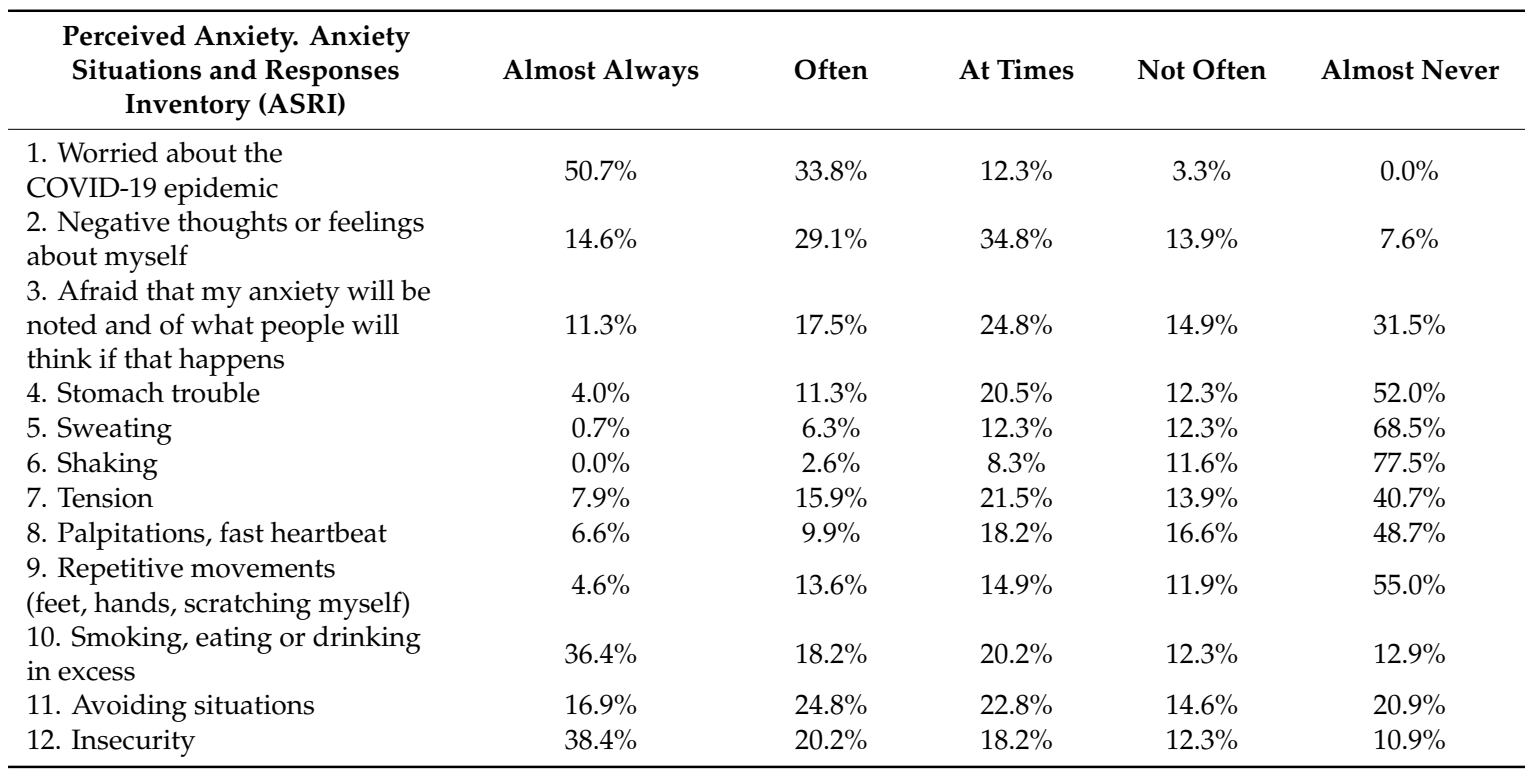

Table 4. Analysis of the anxiety of the podiatrists.

\begin{tabular}{|c|c|c|c|c|c|}
\hline & $\begin{array}{l}\text { Perceived Anxiety } \\
\text { (ASRI) Total }\end{array}$ & SE & Cognitive (ASRI) & Physiological (ASRI) & Motor (ASRI) \\
\hline & $\times 2$ ou $(p)$ & & $\times 2$ ou $(p)$ & $\times 2$ ou $(p)$ & $\chi 2 \circ \mathrm{u}(p)$ \\
\hline Gender $^{\alpha}$ & $6765\left(0.001^{* * *}\right)$ & $0.06^{\&}$ & $6929\left(0.001^{* * *}\right)$ & $7478\left(0.001^{* * *}\right)$ & $7854\left(0.002^{* * *}\right)$ \\
\hline Level of studies $^{\dagger}$ & $2.30(0.316)$ & $0.01^{\#}$ & $1.99(0.369)$ & $5.76(0.055)$ & $5.38(0.068)$ \\
\hline Employment situation $^{+}$ & $0.512(0.774)$ & $0.04^{\#}$ & $0.532(0.776)$ & $4.01(0.135)$ & $1.39(0.498)$ \\
\hline Marital status ${ }^{+}$ & $6.38(0.041 *)$ & 0.02 \# & $5.30(0.070)$ & $3.72(0.155)$ & $6.62(0.032 *)$ \\
\hline $\begin{array}{c}\text { Children }<18 \text { years in } \\
\text { the home }\end{array}$ & $10907(0.658)$ & 0.01 \# & $11260(0.953)$ & $11,145(0.831)$ & $10644(0.379)$ \\
\hline $\begin{array}{l}\text { I have completely cancelled } \\
\text { my professional activity }\end{array}$ & $5.53\left(0.019^{* *}\right)$ & $0.02 \#$ & $2.23(0.135)$ & $8.96\left(0.003^{* * *}\right)$ & $4.26(0.039 *)$ \\
\hline $\begin{array}{l}\text { I believe it will have an } \\
\text { economic impact on my } \\
\text { work future }{ }^{+}\end{array}$ & $8.56\left(0.014^{*}\right)$ & $0.03^{\#}$ & $5.18(0.075)$ & $9.36\left(0.009^{* *}\right)$ & $7.23(0.027 *)$ \\
\hline $\begin{array}{l}\text { I consider the information } \\
\text { received from the competent } \\
\text { health authorities to } \\
\text { be sufficient }{ }^{+}\end{array}$ & $21.36(0.001 *)$ & $0.03^{\#}$ & $19.42(0.001 *)$ & $13.46(0.001 *)$ & $9.63(0.002 *)$ \\
\hline Severity of COVID- $19^{+}$ & $40.3\left(0.001^{* * *}\right)$ & $0.13^{\&}$ & $52.4\left(0.001^{* * *}\right)$ & $14.9\left(0.005^{* *}\right)$ & $24.7\left(0.001^{* * *}\right)$ \\
\hline $\begin{array}{l}\text { Risk of contracting the disease } \\
\text { because of my age or presence } \\
\text { of previous pathologies }{ }^{+}\end{array}$ & $38.3\left(0.001^{* * *}\right)$ & $0.12 \&$ & $39.6\left(0.001^{* * *}\right)$ & $30.0\left(0.001^{* * *}\right)$ & $25.1\left(0.001^{* * *}\right)$ \\
\hline $\begin{array}{l}\text { COVID-19 is harmful for } \\
\text { my health }{ }^{\dagger}\end{array}$ & $38.2\left(0.001^{* * *}\right)$ & $0.11^{\&}$ & $40.1(0.001 * * *)$ & $24.4\left(0.001^{* * *}\right)$ & $34.1\left(0.001^{* * *}\right)$ \\
\hline Perceived susceptibility $^{+}$ & $100.3\left(0.001^{* * *}\right)$ & $0.31^{\$}$ & $98.7\left(0.001^{* * *}\right)$ & $68.5\left(0.001^{* * *}\right)$ & $67.5\left(0.001^{* * *}\right)$ \\
\hline $\begin{array}{l}\text { Perceived possibility of } \\
\text { getting infected }^{+}\end{array}$ & $75.3\left(0.001^{* * *}\right)$ & $0.23^{\$}$ & $77.5\left(0.0011^{* * *}\right)$ & $54.6\left(0.001^{* * *}\right)$ & $48.6\left(0.001^{* * *}\right)$ \\
\hline $\begin{array}{l}\text { Perceived possibility of } \\
\text { getting infected in comparison } \\
\text { with others }{ }^{+}\end{array}$ & $55.1\left(0.001^{* * *}\right)$ & $0.18^{\$}$ & $45.5\left(0.001^{* * *}\right)$ & $43.7\left(0.001^{* * *}\right)$ & $41.5\left(0.001^{* * *}\right)$ \\
\hline $\begin{array}{c}\text { The threat is exaggerated by } \\
\text { the media and } \\
\text { the government }\end{array}$ & $26.1\left(0.001^{* * *}\right)$ & $0.18^{\$}$ & $23.1\left(0.001^{* * *}\right)$ & $14.4\left(0.001^{* * *}\right)$ & $21.4\left(0.001^{* * *}\right)$ \\
\hline $\begin{array}{c}\text { The situation is worse than } \\
\text { what was predicted }\end{array}$ & $14.2\left(0.007^{* *}\right)$ & 0.04 \# & $12.4\left(0.014^{*}\right)$ & $10.46(0.031 *)$ & $8.4(0.076)$ \\
\hline $\begin{array}{l}\text { There is nothing we can do } \\
\text { about it }^{+}\end{array}$ & $3.54(0.472)$ & 0.01 \# & $8.49(0.075)$ & $3.38(0.496)$ & $2.38(0.655)$ \\
\hline $\begin{array}{c}\text { The situation breeds a sense } \\
\text { of powerlessness }\end{array}$ & $32.9\left(0.001^{* * *}\right)$ & $0.11^{\&}$ & $20.9\left(0.001^{* * *}\right)$ & $28.2\left(0.001^{* * *}\right)$ & $27.4\left(0.001^{* * *}\right)$ \\
\hline $\begin{array}{c}\text { Confinement is the } \\
\text { only option }^{+}\end{array}$ & $22.8\left(0.001^{* * *}\right)$ & $0.11 \&$ & $25.1\left(0.001^{* * *}\right)$ & $15.2\left(0.004^{* *}\right)$ & $18.2\left(0.001^{* * *}\right)$ \\
\hline $\begin{array}{l}\text { As a health professional I } \\
\text { consider the information } \\
\text { received from the government } \\
\text { to be reliable }{ }^{+}\end{array}$ & $13.3\left(0.011^{*}\right)$ & $0.11 \&$ & $6.7(0.153)$ & $22.2\left(0.001^{* * *}\right)$ & $13.4\left(0.009^{* *}\right)$ \\
\hline
\end{tabular}

Note: ${ }^{+}$Kruskal-Wallis test; ${ }^{\alpha}$ Mann-Whitney U; ES: effect size.; ${ }^{\&}$ small ES; ${ }^{*}$ medium ES; ${ }^{\$}$ large ES. Significance set at $p<0.05$. ${ }^{*} p<0.05 ;{ }^{* *} p<0.01 ;{ }^{* * *} p<0.001$. 


\section{Discussion}

As health personnel, professional podiatrists are constantly updated with health knowledge and this is why the results of our study show a high level of knowledge about the main characteristics of the COVID-19 disease. Furthermore, these results are similar to those of other studies where the degree of knowledge of COVID-19 has been analysed in health professionals, such as doctors, nurses and pharmacists $[35,36]$. This knowledge takes on more importance in the current situation in which it has been revealed that COVID-19 can appear cutaneously in foot injuries. Specifically, these injuries are similar to acro-ischaemic processes associated with the presence of cyanosis and/or tissue necrosis which can be spontaneously resolved [37,38]. Due to this situation, the General Council of Official Colleges of Podiatry in Spain has set up a web page to register compatible cases which can establish the occurrence of this type of injury in patients with a positive COVID-19 diagnosis [39].

The results obtained through our study reveal the impact, at the work level in professional podiatrists, of the measures taken by the Spanish government during the COVID-19 pandemic. A high percentage of them (76.2\%) completely cancelled their professional activity, and the rest only deal with urgent consultations. This is why a broad percentage of the study's participants consider that this situation will have a strong economic impact on their working future. Additionally, due to the decree of the Spanish government not forcing a total closure of podiatry clinics, they are not able to benefit from certain socio-economic measures aimed at palliating the complete closure of firms.

As to the effectiveness of the measures established in the state of alarm, they are verified as being much more significant once the decree of the state of the alarm was passed. This is due to these measures currently demonstrating their effectiveness in the reduction of infection, hospital/ICU admissions and deaths in comparison with the beginning of the pandemic [24].

The impact of the COVID-19 pandemic on the psychological aspect of health professionals is evident, as has been demonstrated by some studies in which $40 \%$ of the health professionals of Wuhan (China) had problems of anxiety, specifically those exposed on the disease's frontline [40,41]. In turn, another study, carried out in Singapore in February and March, concluded that "non-medical professionals" (health professionals who are neither doctors nor nurses) had a greater level of anxiety than "medical professionals". This was associated with a greater lack of first-hand information, sufficient protection and training and less access to resources of psychological support to confront the problem [42]. Likewise, other studies of similar characteristics in diseases such as the H1N1 virus and severe acute respiratory syndrome (SARS) established high levels of anxiety in health professionals on the disease's frontline, as well as a directly proportional relation between the information received and the perceived anxiety $[43,44]$.

There were significant differences regarding gender. Greater anxiety is shown in women than in men. These results coincide with the study conducted by Lai et al. In this study, we observed greater anxiety in female professionals [41]. However, the healthcare professionals are predominantly female, therefore, this may be a bias to take into account.

Regarding age, in our study, there were no significant differences. On the other hand, Huang et al. concluded that younger people reported a significantly higher prevalence of generalised anxiety disorder and depressive symptoms than older people [45]. Our results may be related to the false feelings of protection on the part of young people against COVID-19. The latest data show a decrease in the average age of those infected.

Finally, marital status was a variable that influenced this population. People who live with other family members have a higher perception of risk. There is no doubt that healthcare professionals have needs at the family level for health, knowledge and safety that are increased in pandemic situations, and may affect their professional performance. The personal concern most frequently related to the COVID-19 outbreak is that related to family health, the risk of transmitting the disease to their family and their patients $[27,46]$.

The data contributed by these studies can be related with the results obtained in our study, which establish a significant level of anxiety in professional podiatrists concerning the current situation. 
Specifically, this anxiety is fundamentally marked by marital status, with the majority of the respondents being married. This could be due to the worry about having the disease and infecting their partner and family, as well as the lack of an economic income essential for the whole family. The perceived susceptibility and the possibility of getting infected are situations which also breed a huge sense of powerlessness in professional podiatrists. This increases their levels of anxiety as well.

This research reveals the shortages suffered by health staff who are not backed by the public health system. Additionally, there is the aggravating fact that their professional practice takes place totally in the private sector. Emergencies do not overcome the economic needs of these professionals. Added to this is that a high percentage of their users are people at risk (the elderly) and that these people must rigorously maintain social distancing. Therefore, this group should be included in the economic help given to the self-employed, thus avoiding social and economic deprivation. On the other hand, these results can be extrapolated to professions whose characteristics are similar (physiotherapists, dentists, etc.). One must not forget that these groups give an important service to the population and a region's care quality depends on their survival.

A limitation of our study is not having a control group for comparison with a non-health group or a comparison with health workers practising in the public sector.

\section{Conclusions}

Podiatry professionals show a broad knowledge of the clinical characteristics of COVID-19 in relation to updated information on the disease and other studies on the knowledge of health professionals, and are also health personnel able to detect foot symptoms associated with it. The measures adopted by the government regarding their work situation is not to their liking.

Likewise, they are affected by a high level of anxiety (the situation breeds a sense of powerlessness) associated with the COVID-19 pandemic due to its economic impact as they are self-employed. As well as not being able to generate necessary incomes, they have the possibility of suffering from or transmitting the disease in their environment. These data can be extrapolated to professionals with identical work situations, such as dentists and physiotherapists.

Author Contributions: Conceptualisation, S.V.-P. and M.P.-C.; Investigation, S.V.-P., M.P.-C. and A.C.-M.; Methodology, A.C.-M. and M.L.G.-E.; Writing—review and editing, L.R.-B., M.P.-C., I.R.-G. and M.L.G.-E. All authors have read and agreed to the published version of the manuscript.

Funding: This research received no external funding.

Conflicts of Interest: The authors declare no conflict of interest.

\section{References}

1. Cascella, M.; Rajnik, M.; Cuomo, A.; Dulebohn, S.C.; Di Napoli, R. Features, evaluation and treatment coronavirus (COVID-19). In StatPearls; StatPearls Publishing: Treasure Island, FL, USA, 2020. Available online: http://www.ncbi.nlm.nih.gov/books/NBK554776/ (accessed on 31 March 2020).

2. Guo, Y.-R.; Cao, Q.-D.; Hong, Z.-S.; Tan, Y.-Y.; Chen, S.-D.; Jin, H.-J.; Tan, K.S.; Wang, D.Y.; Yan, Y. The Origin, Transmission and Clinical Therapies on Coronavirus Disease 2019 (COVID-19) Outbreak-An Update on the Status. Mil. Med. Res. 2020, 7, 11. [CrossRef] [PubMed]

3. Perlman, S.; Netland, J. Coronaviruses post-SARS: Update on replication and pathogenesis. Nat. Rev. Microbiol. 2009, 7, 439-450. [CrossRef] [PubMed]

4. Lu, R.; Zhao, X.; Li, J.; Niu, P.; Yang, B.; Wu, H.; Wang, W.; Song, H.; Huang, B.; Zhu, N.; et al. Genomic characterisation and epidemiology of 2019 novel coronavirus: Implications for virus origins and receptor binding. Lancet 2020, 395, 565-574. [CrossRef]

5. Yin, Y.; Wunderink, R.G. MERS, SARS and other coronaviruses as causes of pneumonia. Respirology 2018, 23, 130-137. [CrossRef] [PubMed] 
6. Giovanetti, M.; Benvenuto, D.; Angeletti, S.; Ciccozzi, M. The First Two Cases of 2019-nCoV in Italy: Where They Come From? J. Med. Virol. 2020, 92, 518-521. [CrossRef] [PubMed]

7. Zhou, P.; Yang, X.-L.; Wang, X.-G.; Hu, B.; Zhang, L.; Zhang, W.; Si, H.R.; Zhu, Y.; Li, B.; Huang, C.L.; et al. A Pneumonia Outbreak Associated with a New Coronavirus of Probable Bat Origin. Nature 2020, 579, 270-273. [CrossRef] [PubMed]

8. Guan, W.-J.; Ni, Z.-Y.; Hu, Y.; Liang, W.-H.; Ou, C.-Q.; He, J.-X.; Liu, L.; Shan, H.; Lei, C.L.; Hui, D.S.; et al. China Medical Treatment Expert Group for Covid-19. Clinical Characteristics of Coronavirus Disease 2019 in China. N. Engl. J. Med. 2020, NEJMoa2002032. [CrossRef]

9. Li, Q.; Guan, X.; Wu, P.; Wang, X.; Zhou, L.; Tong, Y.; Ren, R.; Leung, K.S.M.; Lau, E.H.Y.; Wong, J.Y.; et al. Early Transmission Dynamics in Wuhan, China, of Novel Coronavirus-Infected Pneumonia. N. Engl. J. Med. 2020, 382, 1199-1207. [CrossRef]

10. He, F.; Deng, Y.; Li, W. Coronavirus Disease 2019: What We Know? J. Med. Virol. 2020, 382, 1708-1720. [CrossRef]

11. De Sanidad, M. How Is the New Coronavirus Transmitted? Available online: https://www.mscbs.gob.es/ en/profesionales/saludPublica/ccayes/alertasActual/nCov-China/img/COVID19_como_se_transmite.jpg (accessed on 31 March 2020).

12. Wang, W.; Tang, J.; Wei, F. Updated understanding of the outbreak of 2019 novel coronavirus (2019-nCoV) in Wuhan, China. J. Med. Virol. 2020, 92, 441-447. [CrossRef]

13. Chan, J.F.-W.; Yuan, S.; Kok, K.-H.; To, K.K.-W.; Chu, H.; Yang, J.; Xing, F.; Liu, J.; Yip, C.C.-Y.; Poon, R.W.-S.; et al. A Familial Cluster of Pneumonia Associated with the 2019 Novel Coronavirus Indicating Person-to-Person Transmission: A Study of a Family Cluster. Lancet 2020, 395, 514-523. [CrossRef]

14. Wang, D.; Hu, B.; Hu, C.; Zhu, F.; Liu, X.; Zhang, J.; Wang, B.; Xiang, H.; Cheng, Z.; Xiong, Y.; et al. Clinical Characteristics of 138 Hospitalized Patients With 2019 Novel Coronavirus-Infected Pneumonia in Wuhan, China. JAMA 2020, 323, 1061. [CrossRef] [PubMed]

15. Wu, Z.; McGoogan, J.M. Characteristics of and Important Lessons from the Coronavirus Disease 2019 (COVID-19) Outbreak in China. JAMA 2020, 323, 1239. [CrossRef]

16. Chen, N.; Zhou, M.; Dong, X.; Qu, J.; Gong, F.; Han, Y.; Qiu, Y.; Wang, J.; Liu, Y.; Wei, Y.; et al. Epidemiological and Clinical Characteristics of 99 Cases of 2019 Novel Coronavirus Pneumonia in Wuhan, China: A Descriptive Study. Lancet 2020, 395, 507-513. [CrossRef]

17. Bai, Y.; Yao, L.; Wei, T.; Tian, F.; Jin, D.-Y.; Chen, L.; Wang, M. Presumed Asymptomatic Carrier Transmission of COVID-19. JAMA 2020, 323, 1406. [CrossRef] [PubMed]

18. Liu, Z.; Bing, X.Z.; Zhi, X. The Novel Coronavirus Pneumonia Emergency Response Epidemiology Team. The Epidemiological Characteristics of an Outbreak of 2019 Novel Coronavirus Disease (COVID-19). Chin. J. Epidemiol. 2020, 41, 145-151. [CrossRef]

19. National Institutes of Health (NIH). Coronavirus (COVID-19). Available online: https://www.nih.gov/healthinformation/coronavirus (accessed on 1 April 2020).

20. De Sanidad, M. Información Científica-Técnica. Enfermedad por Coronavirus, COVID-19. Available online: https://www.mscbs.gob.es/profesionales/saludPublica/ccayes/alertasActual/nCov-China/ documentos/20200404_ITCoronavirus.pdf (accessed on 20 April 2020).

21. Lu, H. Drug treatment options for the 2019-new coronavirus (2019-nCoV). Biosci. Trends 2020, 14, 69-71. [CrossRef] [PubMed]

22. Wang, M.; Cao, R.; Zhang, L.; Yang, X.; Liu, J.; Xu, M. Remdesivir and Chloroquine Effectively Inhibit the Recently Emerged Novel Coronavirus (2019-nCoV) in Vitro. Cell Res. 2020, 30, 269-271. [CrossRef]

23. World Health Organization. Coronavirus Disease (Covid-19) Pande. 2019. Available online: https: //www.who.int/emergencies/diseases/novel-coronavirus-2019 (accessed on 7 October 2020).

24. Ministry of Health. (Spain) Situation of COVID-19 or Coronavirus in Spain. Available online: https: //covid19.isciii.es/ (accessed on 7 October 2020).

25. Boletín Oficial del Estado. (Spain) Disposiciones Generales Ministerio de la Presidencia, Relaciones con las Cortes y Memoria Democrática. Available online: https://www.boe.es/boe/dias/2020/03/14/pdfs/BOE-A-20203692.pdf (accessed on 1 April 2020). 
26. Ley Disposición General. (España) Real Decreto-ley 10/2020, de 29 de Marzo, por el que se Regula un Permiso Retribuido Recuperable para las Personas Trabajadoras por Cuenta Ajena que no Presten Servicios Esenciales, con el fin de Reducir la Movilidad de la Población en el Contexto de la Lucha Contra el COVID-19. Available online: https://www.boe.es/buscar/doc.php?id=BOE-A-2020-4166 (accessed on 1 April 2020).

27. García-Iglesias, J.J.; Gómez-Salgado, J.; Martín-Pereira, J.; Fagundo-Rivera, J.; Ayuso-Murillom, D.; Martínez-Riera, J.R.; Ruiz-Frutos, C. Impacto del SARS-CoV-2 (Covid-19) en la salud mental de los profesionales sanitarios: Una revisión sistemática [Impact of SARS-CoV-2 (Covid-19) on the mental health of healthcare professionals: A systematic review]. Rev. Esp. Salud Publica 2020, 94, e202007088. (In Spanish) [PubMed]

28. World Medical Association. World Medical Association Declaration of Helsinki. Ethical Principles for Medical Research Involving Human Subjects. Bull. World Health Organ. 2001, 79, 373-374.

29. Bults, M.; Beaujean, D.J.; De Zwart, O.; Kok, G.; Van Empelen, P.; E Van Steenbergen, J.; Richardus, J.H.; Voeten, H.A. Perceived Risk, Anxiety, and Behavioural Responses of the General Public during the Early Phase of the Influenza A (H1N1) Pandemic in the Netherlands: Results of Three Consecutive Online Surveys. BMC Public Health 2011, 11, 2. [CrossRef] [PubMed]

30. Brug, J.; Aro, A.R.; Oenema, A.; de Zwart, O.; Richardus, J.H.; Bischop, G.D. SARS risk perception, knowledge, precautions, and information sources, the Netherlands. Emerg. Infect. Dis. 2004, 10, 1486-1489. [CrossRef] [PubMed]

31. De Zwart, O.; Veldhuijzen, I.K.; Elam, G.; Aro, A.R.; Abraham, T.; Bishop, G.D.; Richardus, J.H.; Brug, J. Avian influenza risk perception, Europe and Asia. Emerg. Infect. Dis. 2007, 13, 290-293. [CrossRef] [PubMed]

32. Cano-Vindel, A.; Miguel-Tobal, J.J. Evaluación de La Ansiedad Desde Un Enfoque Interactivo y Multidimensional: El Inventario de Situaciones y Respuestas de Ansiedad-ISRA. Psicol. Contemp. Psycnet. Apa. Org. 1999, 6, 14-21.

33. Faul, F.; Erdfelder, E.; Buchner, A.; Lang, A.G. Statistical power analyses using G* Power 3.1: Tests for correlation and regression analyses. Behav. Res. Methods 2009, 41, 1149-1160. [CrossRef]

34. Álvarez, R. Estadística Aplicada a las Ciencias de la Salud; de Santos, D., Ed.; Diaz de Santos: Madrid, Spain, 2007.

35. Saqlain, M.; Munir, M.M.; Rehman, S.U.; Gulzar, A.; Naz, S.; Ahmed, Z.; Tahir, A.H.; Mashhood, M. Knowledge, attitude, practice and perceived barriers among healthcare workers regarding COVID-19: A cross-sectional survey from Pakistan. J. Hosp. Infect. 2020, 105, 419-423. [CrossRef]

36. Gohel, K.H.; Patel, P.B.; Shah, P.M.; Patel, J.R.; Pandit, N.; Raut, A. Knowledge and perceptions about COVID-19 among the medical and allied health science students in India: An online cross-sectional survey. Clin. Epidemiol. Glob. Health 2020. [CrossRef]

37. Zhang, Y.; Cao, W.; Xiao, M.; Li, Y.J.; Yang, Y.; Zhao, J.; Zhou, X.; Jiang, W.; Zhao, Y.Q.; Zhang, S.Y.; et al. Clinical and Coagulation Characteristics of 7 Patients with Critical COVID-2019 Pneumonia and Acro-Ischemia. Zhonghua Xue Ye Xue Za Zhi 2020, 41, E006. [CrossRef]

38. Mazzota, F.; Troccoli, T. Acute Acro-Ischemia in the Child at the Time of COVID-19. Available online: http://sectcv.es/wp-content/uploads/2020/04/acroischemia-ENG.pdf (accessed on 10 April 2020).

39. Consejo General de Colegios Oficiales de Podólogos. Registro de Casos Compatibles COVID-19-(CGCOP). Available online: https://cgcop.es/2020/04/09/registro-de-casos-compatibles-covid-19/ (accessed on 10 April 2020).

40. Huang, J.Z.; Han, M.F.; Luo, T.D.; Ren, A.K.; Zhou, X.P. Mental Health Survey of 230 Medical Staff in a Tertiary Infectious Disease Hospital for COVID-19. Zhonghua Lao Dong Wei Sheng Zhi Ye Bing Za Zhi 2020, 38, E001. [CrossRef]

41. Lai, J.; Ma, S.; Wang, Y.; Cai, Z.; Hu, J.; Wei, N.; Wu, J.; Du, H.; Chen, T.; Li, R.; et al. Factors Associated with Mental Health Outcomes Among Health Care Workers Exposed to Coronavirus Disease 2019. JAMA Netw. Open 2020, 3, e203976. [CrossRef]

42. Tan, B.Y.Q.; Chew, N.W.S.; Lee, G.K.H.; Jing, M.; Goh, Y.; Yeo, L.L.L.; Zhang, K.; Chin, H.-K.; Ahmad, A.; Khan, F.A.; et al. Psychological Impact of the COVID-19 Pandemic on Health Care Workers in Singapore. Ann. Intern. Med. 2020. [CrossRef] [PubMed]

43. McAlonan, G.M.; Lee, A.M.; Cheung, V.; Cheung, C.; Tsang, K.W.T.; Sham, P.C.; E Chua, S.; Wong, J.G.W.S. Immediate and Sustained Psychological Impact of an Emerging Infectious Disease Outbreak on Health Care Workers. Can. J. Psychiatry 2007, 52, 241-247. [CrossRef] [PubMed] 
44. Goulia, P.; Mantas, C.; Dimitroula, D.; Mantis, D.; Hyphantis, T. General Hospital Staff Worries, Perceived Sufficiency of Information and Associated Psychological Distress during the A/H1N1 Influenza Pandemic. BMC Infect. Dis. 2010, 10, 322. [CrossRef] [PubMed]

45. Huang, Y.; Zhao, N. Generalized anxiety disorder, depressive symptoms and sleep quality during COVID-19 outbreak in China: A web-based cross-sectional survey. Psychiatry Res. 2020, 288, 112954. [CrossRef]

46. He, K.; Stolarski, A.; Whang, E.; Kristo, G. Addressing General Surgery Residents' Concerns in the Early Phase of the COVID-19 Pandemic. J. Surg. Educ. 2020, 1-4. [CrossRef]

Publisher's Note: MDPI stays neutral with regard to jurisdictional claims in published maps and institutional affiliations.

(C) 2020 by the authors. Licensee MDPI, Basel, Switzerland. This article is an open access article distributed under the terms and conditions of the Creative Commons Attribution (CC BY) license (http://creativecommons.org/licenses/by/4.0/). 